SILVA, Nilson Adauto Guimarães da. A revolta na obra de Albert Camus: posicionamento no campo literário, gênero, estética e ética. (Tese de Doutorado em Letras Neolatinas. Rio de Janeiro, Faculdade de Letras da UFRJ, 2008, 210 p.)

\title{
Por amor à ReVolta: Nilson Adauto DIANTE DA OBRA DE CAMUS
}

Se uma tese deve conter uma tese, se uma tese deve oferecer uma nova perspectiva sobre seu corpus, Nilson Adauto da Silva é autor de uma bela Tese de Doutorado em Letras Neolatinas. Mas, se uma tese não pode ser confundida com um ensaio, então já seria o caso de reconsiderar-se essa certeza.

A tese de Nilson Adauto, Professor Adjunto da Universidade Federal de Viçosa, realmente passa a ser uma obra sem a qual não é mais possível estudar Camus. Seu ingresso na fortuna crítica, no entanto, não se dá por outra via que não a das idéias. Trata-se de um ensaio que contém uma tese, ou poderíamos considerá-lo uma tese cuja linguagem agradável e de generosa clareza pode irmaná-la aos melhores ensaios críticos.

$\mathrm{O}$ ensaio parte de uma premissa fundamental: a revolta e o absurdo são dois dos motores de toda a obra de Camus. Não é a tese de Nilson Adauto que o diz, mas este seu resenhista e leitor, a quem a tese tão claramente mostrou isso.

O autor apresenta como "fio condutor" da obra camusiana o mito, em especial o mito clássico. No esquema proposto pela tese, o absurdo se desenvolve sob a égide do mito Sísifo, e a revolta toma como epítome a figura de Prometeu. Esses signos que também referenciam e reverenciam a identidade européia norteiam a urdidura de uma literatura que não reconheceu suas fronteiras com a filosofia.

Nilson Adauto afirma que Camus "desenvolveu de maneira própria” os mitos gregos de que se vale. Poderíamos, contudo, a partir da própria tese, sugerir que Camus tenha capturado os elementos que, nas versões dos mitos sobre os quais ele mostra tanto conhecimento, tenham interessado de forma plural aos projetos de inserção do humano no centro das especulações e ações do próprio homem.

A tese propõe uma decodificação do uso dos mitos gregos por Camus, e, para isso, investiga seu ambiente de formação e seu 
universo referencial. O leitor da tese é convidado às leituras de Camus, as que ele realizou, e a um mergulho em seu espírito. De uma educação baseada num roteiro que se pode identificar como neo-tomista, comum nas melhores escolas francesas, Nilson Adauto identifica, como herança, o amor pela razão despertada por Plotino e o sentido maior da "angústia trágica" tal como a expressa a obra de Santo Agostinho.

A formação neo-tomista, no entanto, não garantiu a Camus um convívio pacífico com o catolicismo. Para seguir a tese, ao mesmo tempo em que ele "demonstra uma simpatia pelo cristianismo, considerando-o [...] uma espécie de heroísmo espiritual”, há, por outro lado, "uma desconfiança ante o providencialismo cristão".

Desde o primeiro escrito de Camus vindo à luz, a fé e a razão, segundo Nilson Adauto, são dois extremos que não satisfazem sua voracidade de saber e nem sua gana de viver.

O mesmo binômio que, segundo Nilson Adauto, serve de espinha dorsal à obra de Camus, sustenta também a sua tese. Absurdo e revolta conduzem a argumentação da tese, e, ao passo que se apóiam em certa leitura peculiar dos elementos míticos da tradição clássica, conduzem, em seu outro extremo, aos inevitáveis confrontos que a sofrida primeira metade do século XX impunha. Conflitos também - e talvez sobretudo - de idéias. É assim que tanto a revolta quanto o absurdo levam Camus a uma relação com Jean-Paul Sartre que Nilson Adauto soube explorar de forma incomum.

Escrevo aqui "incomum", esperando com isso poder dizer que essa famosa querela, tão explorada à época - e mesmo depois - pela imprensa dita "cultural", não é comumente pensada pelo ponto de vista proposto pela tese. Desde o começo de sua exposição sobre essa querela, Nilson Adauto a analisa enquanto discurso, a partir da noção de "campo" proposta por Pierre Bourdieu. E, para chegar a isso, o texto de Nilson parte de considerações sobre a formação de Sartre, até chegar a propostas de novas perspectivas sobre a posição filosófica de Camus perante o existencialismo, que o interessa, segundo a Tese, tanto quanto fale sobre o tema do absurdo. Da mesma forma, a tese propõe que o pensamento camusiano tenha se divorciado do existencialismo em nome de uma esperança, ou, segundo o texto de Nilson Adauto, quando "acredita que tais conclusões são contraditórias às premissas", uma fuga que só pode levar ao "transcendente, [à] história absolutizada, ou [a] um princípio racional unificador do real", o que, lembra o texto da tese, Camus considerava um "suicídio filosófico". 
Ao falar da querela Sartre-Camus, Nilson Adauto, com um texto que estrategicamente oscila entre a narração, a descrição e a reflexão, desenha com beleza e precisão uma cena enunciativa. E ainda assim, não é o desenho a bico de pena que constitui a sua maior contribuição para o estudo da obra de Camus. Tampouco o é a extensa exposição sobre o problema taxonômico de gênero que a obra de Camus suscita. Mesmo porque a mútua freqüentação dos gêneros na obra camusiana é explicada, pela tese, da seguinte maneira: "se fosse adotada uma apresentação sistemática demais, a filosofia do Absurdo e da Revolta seria deformada."*

Revolta e Absurdo, na tese, sempre em caixa-alta, não são palavras-chave da obra de Camus, porque não redundam em tema; não são cifras, porque, assim como a tese de Nilson Adauto, a obra camusiana é clara, e não são metas, porquanto não estão, em nenhum sentido, no fim. São, pelo que comprova tão bem a tese, os sustentáculos de um pensamento e de uma ideologia que não encontrariam conforto em nenhuma classificação, mas que encontram, nesses dois pilares, seu desconforto ideal, portanto, o seu motor, como já foi dito.

Sobraram, na tese, algumas poucas páginas, umas seis ou sete das duzentas que formam o todo, justamente as seis ou sete próximas do final, sem as quais o texto ganharia um pouco. Isso porque são nessas poucas páginas em que o autor parece querer atestar a pertinência imediata de uma tese da qual o leitor já teria lido quase duzentas páginas que se justificam, cada uma delas, por si. Nesse momento, entra um século XXI um tanto torto e um Brasil que não tem muito motivo de estar ali.

Mas o tom prevalecente é logo retomado, e - o que agrada a todos - temos um final que realmente atinge as mentes e os coraçôes dos leitores de Camus: a confluência entre a ética e a estética reafirma os dois baluartes de sua obra e ressoa o ideal helênico que o sub-capítulo "Camus e a Grécia clássica” ilustra.

Ler a tese de Nilson Adauto é, pois, adiantar-se na leitura de um texto que, publicado para além das pobres prateleiras institucionais, terá a projeção de um ensaio com potência para tornarse referencial. 